\title{
Paratesticular Melanotic Neuroectodermal Tumor
}

National Cancer Institute

\section{Source}

National Cancer Institute. Paratesticular Melanotic Neuroectodermal Tumor. NCI

Thesaurus. Code C162487.

A rare neoplasm that arises from the paratesticular structures and is characterized by the presence of a mixture of melanin-containing epithelial cells and smaller neuroblastlike cells. It usually occurs in infants and has a benign clinical course. 